\title{
STRATEGIC CHANGE IN PROCUREMENT ORIENTATION IN THE SOUTH AFRICAN AUTOMOTIVE INDUSTRY: A CASE STUDY
}

\author{
C.E. Kalenga ${ }^{1}$ and A.C. Brent ${ }^{2}$ \\ Chair: Life Cycle Engineering \\ Department of Engineering and Technology Management \\ University of Pretoria, South Africa \\ alan.brent@up.ac.za
}

\begin{abstract}
The South African automotive industry faces increasing challenges for Original Equipment Manufacturers (OEMs) and their suppliers to produce high-quality products at low costs. Items purchased by OEMs from the supply chain typically account for more than seventy percent of the total costs of manufactured automobiles. The strategic significance of the purchasing function is subsequently recognised as a major determinant of competitiveness. From a review of literature, a conceptual model is introduced whereby localisation strategies of OEMs, with respect to their main suppliers, can be optimised for competitive advantage. The findings of a case study of a South African OEM's localisation strategies are presented. Based on the findings, an improved model is proposed that could be used as a guideline to orientate procurement strategies for optimal performance, so as to guarantee the competitive advantage of local OEMs. It is anticipated that these results will provide a platform of effective strategy development for the South African OEMs.
\end{abstract}

\section{OPSOMMING}

Verskeie uitdagings, met die klem op vervaardiging van hoë-kwaliteit produkte teen verlaagde koste, word in die gesig gestaar deur beide die Oorspronklike Toerusting Vervaardigers (OTVs) en hulle verskaffers in die Suid-Afrikaanse motorindustrie. Items wat OTVs van hul verskaffers verkry verteenwoordig tipies meer as sewentig persent van die totale vervaardigingskoste van motors. Die strategiese implikasie van die aankopingsfunksie word dus erken as belangrike aanwysing van ' $n$ goeie kompeterende basis. ' $n$ Konseptuele model word neergelê gebaseer op 'n oorsig van die literatuur, waardeur die lokaliseringsstrategieë van OTVs, in terme van hulle verskaffers, geoptimiseer kan word as kompeterende voordele. Die bevindinge van 'n Suid-Afrikaanse OTV, as gevallestudie, se lokaliseringsstrategieë word verder voorgelê. Deur hierdie bevindinge word ' $n$ verbeterde model voorgestel wat moontlik gebruik kan word as 'n gids om the aankoopstrategieë te oriënteer ten einde kompeterende voordele te verseker vir plaaslike OTVs. Dit word voorspel dat die resultate van hierdie studie ' $n$ platform daar kan stel vir die effektiewe strategiese ontwikkeling van die Suid-Afrikaanse OTVs.

\footnotetext{
${ }^{1}$ This author was enrolled for the M Eng (Project Management) at the Department of Engineering and Technology Management, University of Pretoria
} 


\section{INTRODUCTION}

Procurement has been defined as the sourcing of resources from outside the performing organisation for it to carry out its business [1]. Included in procurement is the much broader function of managing the process to supply these resources, not just simply buying raw materials, parts and services. Transformation from materials management to supply management poses challenges and opportunities for procurement as well as other functions in the automotive industry. The procurement function has subsequently been recognised as a tool that could be included as part of corporate strategy to gain competitive advantage in the highly competitive automotive industry [2].

\subsection{Historical development and the current state of the procurement function}

In the early 1970s purchasing was viewed as having a passive role in the organisation [3]. Many strategists supported this view in that purchasing was described as an administrative rather than a strategic function. Farmer [4] and Kisser [5], however, stressed the need to include purchasing into corporate planning.

The 1980s, according to Ellram and Carr [6], was a period of recognising the role of purchasing in corporate strategy. As a function, purchasing was claimed to be capable of being a source of competitive advantage for the business. Browning et al. [7] proposed that purchasing could contribute to corporate strategy in four different ways: monitor supply market; interpret the meaning of these trends for the firm; identify the materials and services required to support the company and strategic business unit strategies; and develop supply options. Spekman [8] highlighted the contribution of purchasing in terms of strategic resources and the need to manage key materials in relation to product or market objectives of the particular businesses. By the end of the 1980s Morgan [9] captured the spirit of the pursuit of world-class manufacturing and the need for continuous improvement in terms of cost reduction and improvements in quality, delivery, getting new products to the market faster, and customer responsiveness.

Ellram and Carr [6] observed that the 1990s saw the shift towards integration of purchasing into corporate strategy, the means by which procurement can become a more significant contributor to the company's success, which remains a challenge in South Africa. The current turbulent environmental changes highlight the challenge procurers in the South African automotive industry are facing at present, and will face in the future. The challenge is crucial, as the present has to be managed efficiently and selectively, while reinventing future strategies that will orient procurement to create and sustain competitive advantage. This necessitates the need for a model that will reflect current practices and strategies in automotive project procurement, and will act as a platform to optimise the probabilities of gaining competitive advantage in the automotive sector. 


\subsection{Research problem}

Although the procurement function is increasingly directed to become more strategic in its view and more proactive in terms of its contribution to the corporate planning process, very little progress has been made in the context of South Africa. This results in the need to address where extra efforts should be made in the current procurement strategies to maximise value addition to the value chain. The following research questions were subsequently identified:

- Is the approach to current procurement decisions correct as a base for future decisions?

- Are the current procurement strategies adequate to meet the needs of companies?

- Are the challenges being faced to develop localization strategies in terms of local automotive suppliers similar to those faced when developing general procurement strategies?

\subsection{Objectives}

This study intends to propose and establish a model for the local automotive industry that can assist projects' procurement strategies to leverage a company to establish long-term competitive advantage. The integrated model should provide a roadmap for formulating and implementing procurement policies, assist procurement professionals in automotive industry projects to create and manage change by focusing on the vision of the company, as well as dealing with day-to-day problems and the decision-choices that are encountered.

The study also recommends a set of actions that allows procurement professionals in the automotive industry to react swiftly to the supply market changes and also to internalise customer requirement changes.

\section{THEORETICAL FRAMEWORK}

\subsection{Literature review}

According to Hamel et al [10] the ability to be strategically oriented, remaining focused on long-term objectives, while being flexible enough to react quickly to a rapidly changing environmental forces, has become a key to corporate success. Kanter [11] observes that only purchasing departments that provide value-addition will be maintained in the firm. Priority now lies in identifying the most efficient methods for supplying services and obtaining desired objectives. Miles [12] suggests that the result is the external purchase of services formerly provided within the firm, the development of joint ventures, and partnerships and collaboration between customers and suppliers. Furthermore, shortened automotive product development cycles have necessitated purchasing participation in the design team [13].

Belasco [14] maintains that new strategic approaches contain three elements that can assist a company to determine the correct new direction: 
1. Repositioned products/services to build a competitive advantage;

2. Talented people to execute the new strategies; and

3. Organisational resources that tightly focus on the new strategies.

Significant marketing developments that have taken place, and which are taking place, that highlight the need to form strategic relationships and understandings with both key customers and suppliers, have been identified as [15]:

- The shortening of product life cycles;

- The global development of marketing key product/service;

- The increasing of strategically minded customers; and

- The emergence of new trade blocks, e.g. SADC, NEPAD, EU, etc.

\subsection{Conceptual model}

A framework of supply market forces affecting changes in purchasing has been proposed in the research work of Rajagopal and Bernard [16]. The research also contends that an expanded and more integrated framework can be developed to explain and demonstrate the interaction of forces that can give rise to the necessary changes in purchasing orientation. The framework reflects changes in the environment and in the purchasing function itself and the need for improving performances that can sustain the overall competitive advantage of the firm through achievement in cost, containing improved quality (velocity to market demands/opportunities), and technological superiority.

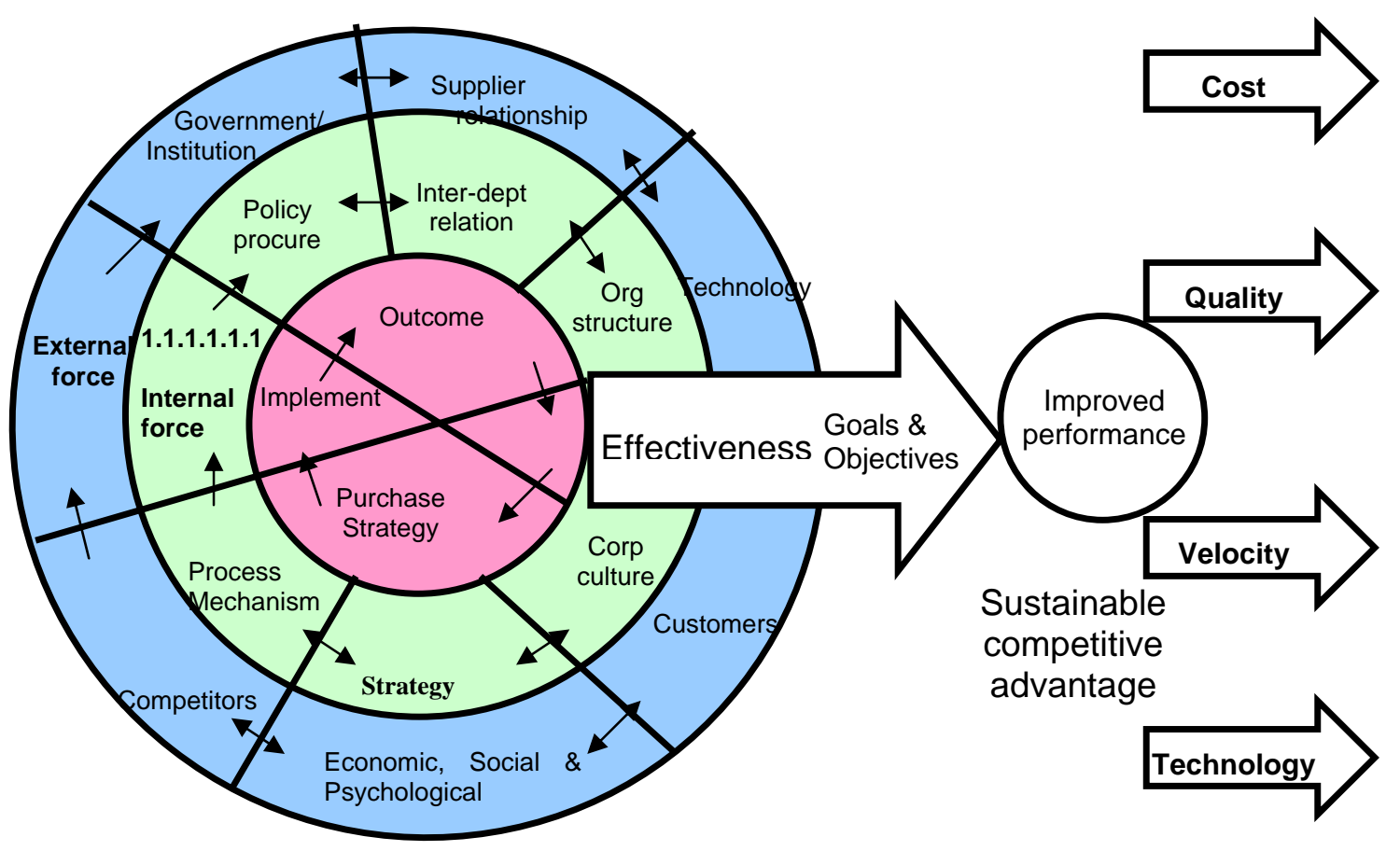

Figure 1: Theoretical framework of supply market forces Affecting procurement performances [16] 
The work of Rajagopal and Bernard [16] shows that the origins of their postulated model (see Figure 1) lie in two separate fields:

- Conceptually in the area of organizational development and change; and

- Empirically in opportunistic but structured observation of evolving practice in two major industries.

The implicit hypothesis rests on the notion of departmental (or micro level) interaction, which takes place in the proactive pursuit of purchasing effectiveness [17]. Porter [18] observed that several authors further propose that the development of effective departmental strategies depends on the prior or contemporaneous existence of strategic interactions between functions at corporate (or macro) level.

As a key contributor to the purchasing function orientation for competitive advantage, the role of supply market forces have been mentioned in the most widely used concepts of Porter [18]. The five-force model has become the best practice used by a large number of successful organisations. A number of generic strategies have been developed that could be customised for specific organisations.

\section{METHODOLOGY}

\subsection{Research strategy}

This research project was based on a case study of the procurement division practices and strategic project management processes of an automotive Original Equipment Manufacturer (OEM) with emphasis on the localization strategy, as a procurement tool, to gain competitive advantage for the OEM in the South African automotive industry. The information obtained was linked to the number of suppliers, pricing strategies, organisational structure, and item-level strategy.

The identification of the appropriate company for the research was not at random as the following selection criteria were applied:

a. A leading automobile manufacturing company in South Africa.

b. A company having direct business relationships with both local and global suppliers that have existed for a period of at least two years.

c. A company that supports the South African government programme of Black Economic Empowerment (BEE).

d. A company in line with and benefiting from the Industrial Participation Program (IPP) through the South African Department of Trade and Industry.

As the focus of the study is on procurement strategies, various respondents who met specific criteria were included in the sample. The main criterion was for purchasing personnel and/or managers who have had direct experience and knowledge over a period of not less than a year with suppliers in the company. Personal interviews were conducted with individuals who met the criteria and each respondent was asked to respond to a statement questionnaire after the interview. 


\subsection{Research instruments}

The following research instruments were used:

- Presentation: An oral presentation to inform about the intentions of the research and its expectations was made to the divisional weekly meeting comprising of all management staff and divisional functional managers. The presentation was then followed by a question and answer session that comprised mainly of clarification issues, schedule of research, key participants and confidentiality clauses.

- Research interviews: Interviews were conducted with the selected respondents, including 3 commodity managers, 14 procurement specialists, 1 supplier development manager, 2 divisional project managers, and the divisional head. In total this constituted a sample of 21 procurement professionals. The strategic project management process usually involves the company tasking a team of professionals, known as a functional group, which carries out a feasibility study of the prospect at hand. They set to achieve a number of objectives that includes:

- Reduction of operational and production costs;

- Improvement of skills through technology transfer;

- Shortened supply chain leading to reduced handling and use of Just In Time;

- Assist in the establishment of a strong clientele and supplier base; and

- Faster conflict resolution, etc.

The selected individual respondents do, on occasion, form part of the functional group. Research questions were formulated to suit each of the four levels of respondents considered. A total of 3 hours was spent with the divisional head, 5 hours with the project managers, 2 hours with each of the commodity managers and the Supplier Development Manager, and 1.5 hours with each of the purchasing specialists. The interviews were conducted over a period of one month.

- Questionnaire: A questionnaire was compiled, which constituted questions regarding the nature and characteristic of the sought strategies in the OEM with respect to the market forces that affect procurement performances (see Figure 1). The questions focused on localization strategies of current purchases. The questions were exploratory in nature in order to gain a deeper understanding of the strategies involved and how they can be aligned to gain competitive advantage. 


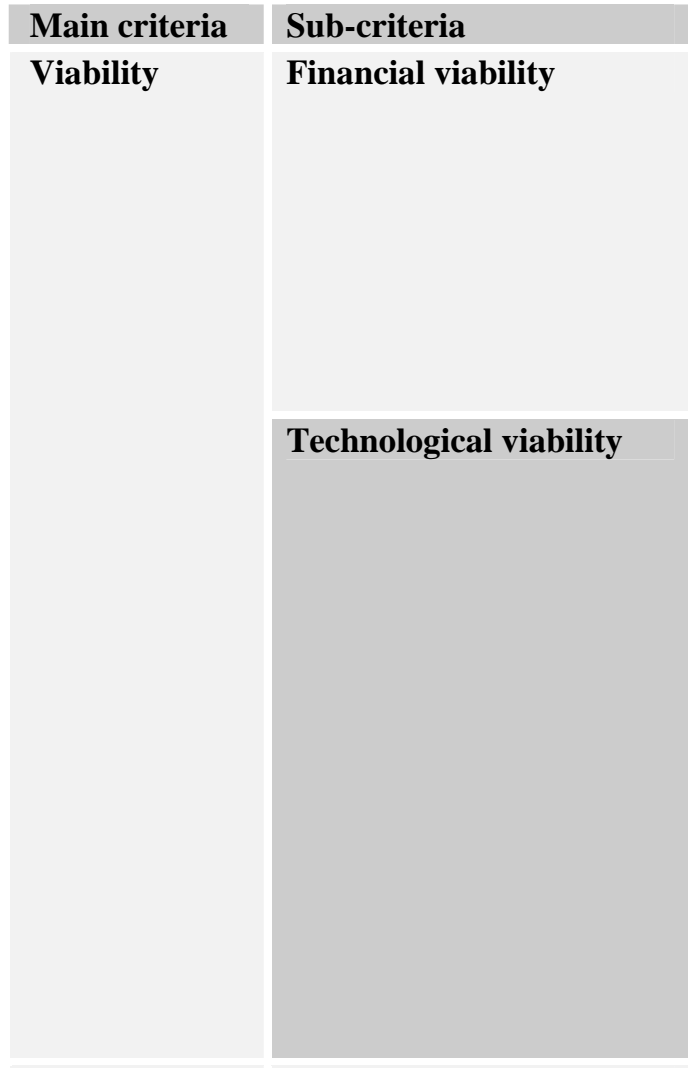

Logistic

Strategic

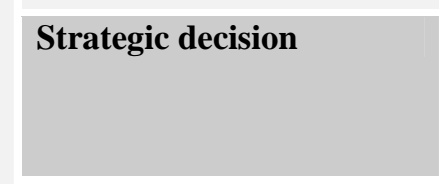

\section{Description}

Parts to be produced locally with a lower price tag compared to the imported parts.

These local parts should have the capabilities for volume bundling and providing export potential to other parent company facilities worldwide.

The other criterion should be to check whether the investment cost would be amortized with four years or with the remaining model life, which ever is lesser.

A number of queries would need to be satisfied for the strategy to be viable as proposed in Figure 2. Queries to be satisfied before a go/no-go decision would include:

1. Whether the technology to produce a part is available. If not, can this technology be acquired within viable means?

2. Do current suppliers have the know-how? Should the parent company facilitate a joint venture/partnership for technology transfer to current suppliers?

3. Is the raw material to produce the part available in South Africa? If not, would the development engineer allow substitutes to be used for production?

It is of paramount importance to give due consideration to how efficiently various parts would be moved.

Colour coding

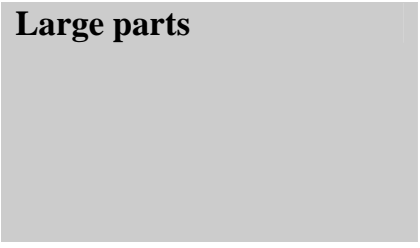

Special care parts

Damaged / defect parts

Corporate initiative

Logistics for large parts that require enormous containers and storage space, e.g. vehicle sidewalls and skin panels. Included in this category would be other large option parts that would make up a major component of the cost of carrying inventory if they were imported, e.g. bumpers.

Logistics for parts requiring special care in handling, e.g. glass.

Logistics for parts with a high rate of damages/defects caused by the many handling points in the import supply chain or charges in environmental conditions.

To encourage local investment and thereby gaining industrial participation credits provided by the DTI under the MIDP programme.

Strategic decision to ensure technology transfer to the South African industry by assisting the company and its supporting industry (suppliers) to attain global competitiveness.

Consideration of colour-coded parts and option driven parts, e.g. cockpits, door panels, etc.

Table 1: Localisation strategy criteria 


\section{RESULTS}

\subsection{Localization strategy criteria}

Considering the focus areas identified to guide its implementation, the localization strategy can be described in terms of viability, logistic, and strategic criteria. These criteria are summarised in Table 1.

\begin{abstract}
Strengths
Existence of a well established local supplier base.

Tacit knowledge exists in the departments to handle localization evidently from the success of work already done on particular projects, e.g. rims, chassis, etc.

Technology sharing agreements through parent company lead buyer.

Shortened supply chain would result in a reduction of handling process, and parts could easily be supplied JIT.

Local vendors able to respond quicker to changes in production schedules.

Faster supplier conflict/ problem resolution, e.g. defective commodities, sudden price changes, wrong orders, etc.

Comparatively lower labour rates, resulting low running costs.

Government import-tax-offset incentives through MIDP.
\end{abstract}

Opportunities
Higher volumes are associated with increased
amortization and overheads per part; alternatively
investment can be amortized over a shorter
period.
Location benefits on competitive criteria: cost,
quality and on-time delivery.
Become a world-class manufacturer.
Produce the cheapest car in a particular range
compared to world competitors.
No forex risk exposure.
Creation of IP credit points for use by sister
companies investing in RSA.

\author{
Weaknesses \\ The 'Big - Brother' syndrome: The company has \\ always been dependant on the parent company \\ for support. \\ Certain technologies are yet to be established in \\ RSA. \\ Low volume inhibits capital-intensive \\ investments. \\ Skill levels are still comparatively lower.
}

Threats

Feared lack of support from the parent company. Late or lack of critical information.

The company might not be integrated into the parent company's function.

Negative viability due to lack of or insufficient local content.

Exchange rate fluctuation.

South African skill levels are feared to be relatively lower.

Local industry might not be sufficient to handle highly sophisticated.

\section{Table 2: SWOT analysis of the localisation strategy}

\subsection{Benefits, risks and shortcomings}

A SWOT (Strength, Weaknesses, Opportunities and Threats) analysis of the localization strategy for assessment purposes is summarised in Table 2. The process 
flow diagram in Figure 2 illustrates the process a procurement strategy undergoes from derivation to implementation. This process would be initiated by a functional group labelled A in the framework. The form, level and objectives of a strategy in a company such as this OEM are quite varied. Despite this fact, a generic methodology is adhered to in the design of an integrated procurement strategy.

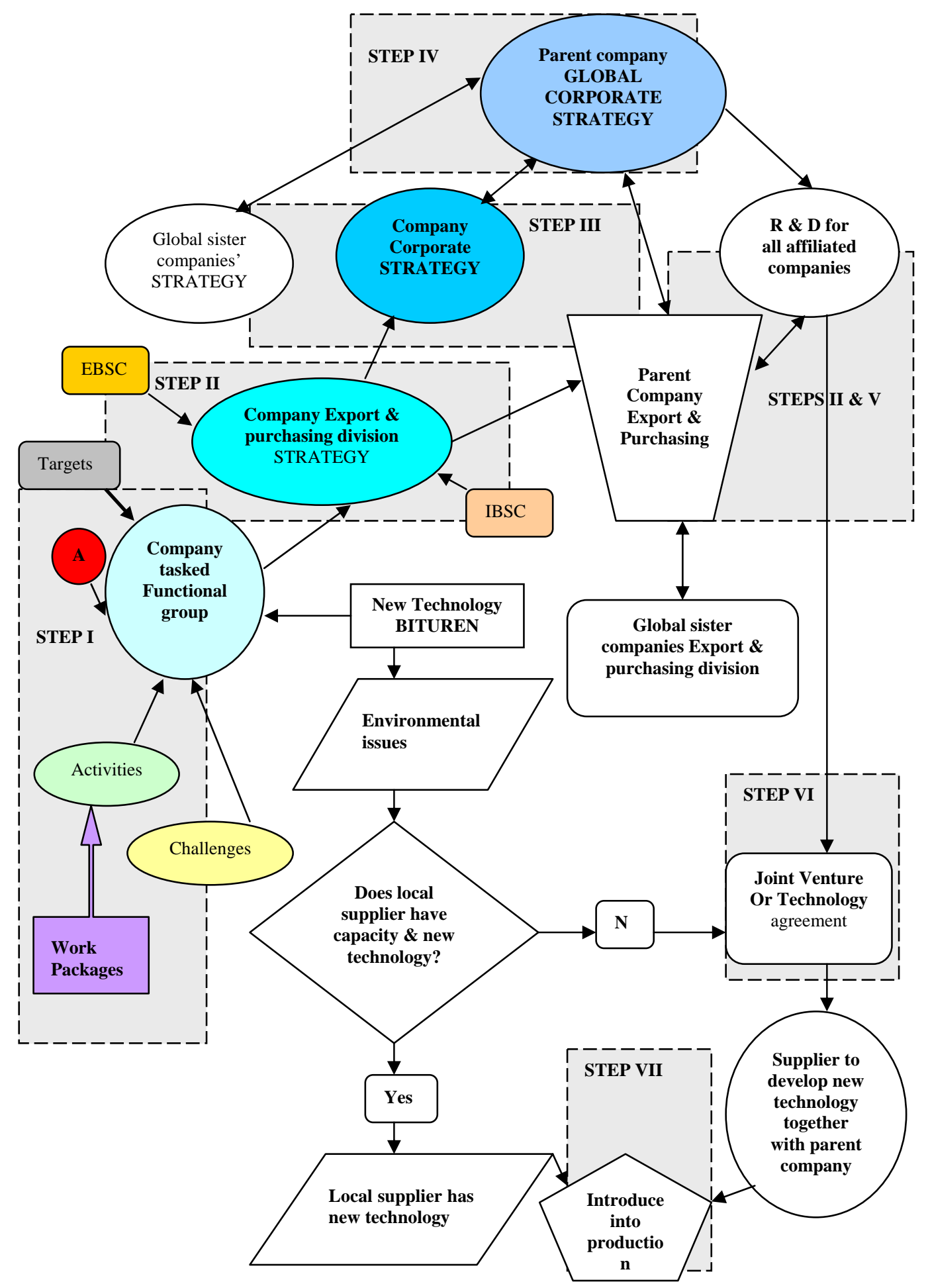

Figure 2: Case study observed framework for developing of an integrated procurement strategy 


\subsection{Case study discussion}

The framework derived from a study of various approaches, as well as the qualitative information collected during the case study shows signs of inter-relationship.

The first connection is in the initial phase, or information gathering stage of the framework. The requirement is the consideration of the internal and external environment factors to appraise the current scenario and set targets of the required outcome, i.e. the localization strategy. This is consistent with the initial requirements of the theoretical established model shown in Figure 2. This stage of the model requires that a consideration of the identified internal and external forces that might influence the formulation of strategy be made first. The entire analysis in both cases focuses on the targets set.

The organisational structure in the form of managerial function then comes into play. In the theoretical model its importance is stated in the facilitation of the overall outcomes of the interaction between internal and external environments. This is then viewed in the successful implementation of strategy, which is reflected in the outcome. A form of metric is also required to measure the level of this success. The empirical results on the other hand illustrates the tasks given to the functional group in the form of work packages and the challenges as inputs to the derivation of strategy, which is then passed on to higher authority.

Metrics are in place in the form of Internal Balanced Scorecard (IBSC) and External Balanced Scorecard (EBSC) approaches to determine the level of success or failure in accordance with the set targets. The senior managers then assess for conformation and checks for acceptance with the parent company where the final decision is made depending on the options available at the parent company. So the managerial influences of both the model and the case study results seem congruent.

The contribution of effective procurement strategy to sustained competitive advantage is finally seen as an achievement through lower cost, higher quality, increased speed to market, and technological breakthroughs. This is because of the significant influence the supplier would have on these factors as illustrated in both the theoretical model and the case study observations.

\section{CONCLUSIONS}

Figure 3 shows the model that has been derived from the propounding of the theoretical model and the information obtained at the OEM Company. This model has a feature of sequential logic that provides an indication of the elements that exhibit the possibility of parallel processing.

The model accomplishes its objective, orientation change strategy through five phases. The first phase involves the recognition of procurement objectives as a subset of corporate objectives. This would be necessary in aligning of strategies to the mission of the company. This alignment would be achieved through the development of a strategic vision that would create and broadcast a "strategic principal". The 
principle then seeks to address the difficulty in achieving decentralised decisionmaking and coherent strategic action by setting clear boundaries within which procurement staff must operate while granting them the freedom to experiment within the constraints. This leads to the identification of Critical Success Factors (CSF).

The next phase involves a systematic review of the supply market forces that would permit the assessment of the availability of external resources in terms of quality, quantity, velocity, technology, and risk.

The relative strength of existing and potential suppliers is important in the strategic options available to the company, especially when faced with global versus local situations. Tools such as Porter's five competitive forces and PESTE (Political, Economic, Social, Technological and Ecological) forces are applied to consolidate a SWOT analysis. The political aspect is quite strong in the local industry with due consideration to Black Economic Empowerment, which the multinational companies must subscribe to. A work package totally dedicated and championed by a strategically minded leader needs to be identified to plan the most effective way to benefit from this cause. The social aspect could be viewed through the government intervention of Affirmative Action, which has become policy for every company to follow.

The phase that follows considers the determination of the decision-making hierarchy of the organisation. This is important to enable effective execution of strategic plans. The hierarchical levels as identified from the theory are classified as competitive strategies, procurement system strategies, and performance-related strategies. Planning, organising, leading, and control are necessary ingredients incorporated in this process. Both short-term and long-term plans depending on the objectives sought must be featured. Competitive Intelligence (CI) is essential in the identification of the Key Intelligence Needs (KIN) that would give the company the edge over its competitors. The answer to one need would generate more questions and it eventually becomes a quality cycle. CI here could be interpreted as doing groundwork in order to answer the questions: How is the strategy made viable to reap the benefits? The question should be answered with the link back to growth and profitability. CI could be seen as necessary information, translated into knowledge that would have a powerful effect on competitive advantage in the form of lower cost, differentiation, and focus.

The value chain position refers to the process by which the company decides what it wants its strategic role to be. In this instance, it is to compete aggressively to maximise its position as a leader in the industry by possessing competitive advantage in the form of a particular localization strategy.

In a business, the goal of making money now and in the future for a shareholder is key. The business case developed from this framework must therefore show how the project would cause shareholder value to increase. The metrics used by shareholders to measure value are the two bottom line metrics of net profit and return on investment (ROI). The final phase is the organisational structure, which affects the 


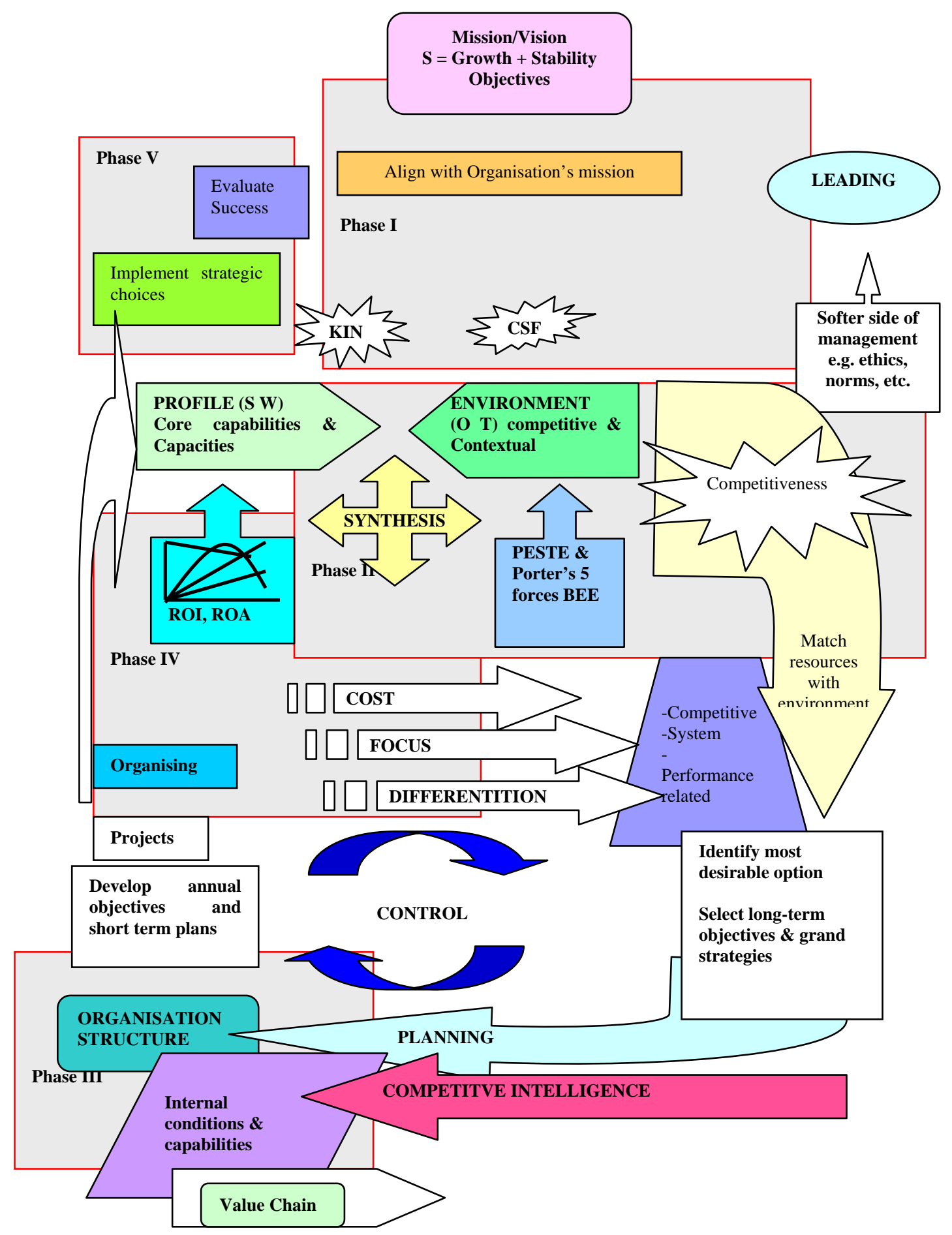

Figure 3: Model for strategic procurement orientation change strategy

coordination of activities, delegation of authority, communication patterns, and task responsibilities, both within the procurement function and between procurement and 
other functional areas of the company. These decisions have an influence upon procurement management's scope and priorities in objective setting, planning, and decision-making. This influence gets even more complex in the case of multinational companies, which is the case in the local industry. Almost all automotive business units in the country have parent companies abroad with which constant collaboration is imperative. Therefore, in order to sustain a competitive advantage, clear communication systems have to be in place, which are sustained by a common communication platform.

\subsection{Implications of the model on practice}

The model expresses several important aspects for procurement. First, a systematic way has to be found to develop an integrated procurement strategy that will enhance procurement management to achieve competitive advantage. Second, the suggested model could serve as a guideline to develop integrated procurement strategies. It also suggests the way of choosing an appropriate strategy in a specific situation. Third, if a company must shift its competitive strategy, the model provides tools to identify necessary changes. Lastly, projects need to be valued in financial terms to provide decision-makers with the information they require when deciding on the viability of the undertaking. This valuation always includes estimates of costs and financial benefits in the form of forecasted outflows and inflows, which can be determined using such financial tools as ROI, Internal Rate of Return (IRR), etc., and are incorporated into the framework.

In strategic thinking, the classification of technological subsystems as strategic and non-strategic is the beginning of a decision tree that would eventually become a map of an organisation's entire strategic sourcing process. Major subsystems that are nonstrategic in the automotive sector, essentially products of mature technologies such as vehicle batteries, tyres, seats, etc., for which there are several qualified suppliers, may easily be outsourced locally.

\section{REFERENCES}

[1] Turner JR, 1995. “The Commercial Project Manager”, Managing owners, sponsors, partners, supporters, stakeholders, contractors and consultants, McGraw Hill book company.

[2] Rajagopal S and Bernard KN, 1993. "Integrated marketing and procurement: a conceptual approach for profitability”, In proceedings of the $21^{\text {st }}$ Annual conference of the European marketing Academy Aarhaus, Denmark.

[3] Ammer DS, 1974. "Is your purchasing department a good buy”? Harvard Business Review.

[4] Farmer SH, 1972. "The impact of supply markets on corporate planning”, Long Range Planning.

[5] Kisser GE, 1976. "Elements of purchasing strategy", Journal of Purchasing and Materials Management.

[6] Ellram LM and Carr AS, 1994. "Strategic purchasing: A history and review of the literature", International Journal of Purchasing and Materials Management. 
[7] Browning JM, Zabrieskie NB and Huellmantel AB, 1983. "Strategic purchasing planning”, Journal of Purchasing and Materials Management.

[8] Spekman RE, 1985. "Competitive procurement strategies: building strength and reducing vulnerability”, Long Range Planning.

[9] Morgan JP, 1989. “Are you aggressive enough for the 1990s”, Purchasing.

[10] Hamel G and Prahalad C, 1989. "Strategic Intent”, Harvard Business review.

[11] Kanter RM, 1989. "When giants learn to dance: Mastering the challenges of strategy, Management and careers in the 1990s", Simon Schuster, New York.

[12] Miles R, 1989. "Adapting to technology and competition: a new industrial relations system for the $21^{\text {st }}$ century”, California management review, 1989.

[13] Botha Z, 2004. "Auto hub has space for more investors”, Engineering News, 2004.

[14] Belasco J, 1990. “Teaching the Elephant to dance”, Hutchinson Business Books, UK.

[15] Handscombe R and Norman P, 1989. "Strategic leadership: The missing links”, McGraw-Hill, UK.

[16] Rajagopal S and Bernard KN, 1994. "Creating strategic change in procurement orientation”, European journal of purchasing \& supply management, Vol. 1.

[17] Hakansson H, 1983. "International Marketing and Purchasing of industrial goods: An Interaction Approach”, Wiley.

[18] Porter ME, 1985 "Competitive Advantage: Creating and Sustaining Superior Performance”, Free Press, New York. 